\title{
The Safety and Security Measures of the Selected Universities in Nueva Ecija, Philippines: Its Combat to COVID-19 Pandemic
}

\author{
Jennilyn C. Mina, Januaryn Jose B. Aydinan, Romeo B. Campos, Jr., Shirley P. Ayeo-eo \\ Nueva Ecija University of Science and Technology, Cabanatuan, Philippines \\ Email: zedka_jen27@yahoo.com, noneaydi@yahoo.com,campos_romeo01@yahoo.com.ph, sayeoeo@gmail.com
}

How to cite this paper: Mina, J.C., Aydinan, J.J.B., Campos, Jr., R.B. and Ayeo-eo, S.P. (2021) The Safety and Security Measures of the Selected Universities in Nueva Ecija, Philippines: Its Combat to COVID-19 Pandemic. Open Access Library Journal, 8: e7076.

https://doi.org/10.4236/oalib.1107076

Received: December 12, 2020

Accepted: January 3, 2021

Published: January 6, 2021

Copyright $\odot 2021$ by author(s) and Open Access Library Inc.

This work is licensed under the Creative Commons Attribution International License (CC BY 4.0).

http://creativecommons.org/licenses/by/4.0/

\begin{abstract}
This study was conducted to describe the existing safety and security measures of the top universities in Nueva Ecija, Philippines towards its combat to COVID-19 pandemic in terms of availability of facilities and equipment, personnel welfare. After identifying the prevailing measures of the universities, the researchers proposed an enhancement plan. The researchers used a descriptive design of methodology by using a questionnaire-checklist to scientifically describe the safety and security measures of the top academic institutions in Nueva Ecija. The respondents of the study were faculty and staff of five established universities in Nueva Ecija, Philippines wherein the researchers employed a non-probability sampling technique to logically undertake as the representative of the entire population. The results of the study have shown that the top universities in Nueva Ecija have made efforts to ensure the safety of university workers by complying with the Inter-Agency Task Force (IATF) protocols. It can be inferred that some areas must be improved especially when it comes to ensuring the welfare of the personnel who are still reporting to work even in this time of the pandemic. The researchers suggested an enhancement plan that can be adapted by these universities to resolve the concerns of the faculty and staff especially in reducing the spread of the virus without sacrificing the day-to-day transactions of the academic institutions.
\end{abstract}

\section{Subject Areas \\ Criminology}

\section{Keywords}

Combat, COVID-19, Inter-Agency Task Force (IATF), Pandemic, Safety and Security, University 


\section{Introduction}

It was a great shock to the Filipino people when a month-long lockdown was declared in the capital region covering the main island of Luzon to contain the spread of the new coronavirus outbreak [1]. Due to the increased number of the COVID-19 infected cases, the Enhanced Community Quarantine was extended and the public was required to stay at home [2]. Almost $90 \%$ of the world was impacted by this global pandemic in such a way that social isolation was enforced [3].

In today's situation, people all over the world are facing the dooms and smoldering ruins of COVID-19. Due to this pandemic crisis, countries around the world took tentative steps toward reopening to bounce back from the coronavirus pandemic [4].

However, as the rise in COVID-19 cases continues, the fear of contracting the virus among employees in their workplaces has led many workers to continue staying at home [5]. Amid this turmoil, businesses have to reopen and many employees have to get back to work and abruptly accept fundamental changes to their work routines [6] which include reopening of the colleges and universities while facing the new normal situation (Anderson, 2020). To improve the progress made in combating infection rates and ensure a safe workplace; government leaders, employers, and employees, and their respective organizations initiated health and safety measures and other protocols to ensure the welfare of all personnel [7].

In the Philippines, the government spearheaded the initiatives to release Interim Guidelines on Workplace Prevention and Control of COVID-19 where workers and employers are required to follow total precautionary measures as the country grapples with the containment of the deadly virus [8]. Unfortunately, despite absolute plans and proposals of IATF, drawbacks, and loopholes occur due to improper and inadequate implementation of the said protocols and indifference of the citizens. Thus, measuring the gap of distance between idealistic and realistic has to be determined to bandage the leakage between concepts and rationalities of today's situation.

The researchers, as faculty members who are physically reporting to work amidst this situation, recognize the importance of determining the precautionary measures of the different universities in Nueva Ecija since this province is considered as high risk as of the 6th of October in this current year [9].

Given the severity of the issues brought by the current crisis and the importance of sustaining the preventive measures in the workplace, the objective of this study is grounded on the tenets of assessing the safety and security measures being implemented by the top five universities in Nueva Ecija, Philippines in terms of facilities and equipment and personnel welfare to further enhance the restrictions and guidelines for the welfare of their faculty and staff who are considered as their greatest assets as they continue to provide quality education even in this time of crisis. 


\section{Methodology}

The descriptive design was used in this research to answer the aforementioned questions. A descriptive study attempts to describe systematically a situation, problem, phenomenon, service, or program or provides information about, say, the living conditions of a community, or describes attitudes towards an issue [10]. The respondents of this study were the 103 faculty and staff of five established universities in the province of Nueva Ecija in the Philippines which was purposively selected. Purposive sampling is a non-probability sampling method and it occurs when elements selected for the sample are chosen by the judgment of the researchers. According to Black [11], in this technique, researchers often believe that they can obtain a representative sample by using sound judgment, which will result in saving time and money. These respondents answered a questionnaire-checklist that has been modified by the researchers based on the standard of the IATF when it comes to the precautionary measures needed in the workplace to avoid the spread of the virus.

\section{Results and Discussion}

\subsection{Respondent's Employment Category}

It can be noted from the illustration (Figure 1) that majority or $62.00 \%$ of the respondents belong to the teaching staff. The fact that no matter what higher education institution one is talking about; faculty play a massive role in the delivery of a world-class student experience [12].

As these universities integrate practical knowledge with theoretical learning, this teaching system requires more faculty members to sustain it since faculty members are a central and critical ingredient to the quality of a higher education institution [13]. Members of the faculty carry out the duties of the institutions where they serve, conduct and perform research, educate students, apply their expertise to solve social issues through their extension services department, and fulfill university or college leadership and service positions.

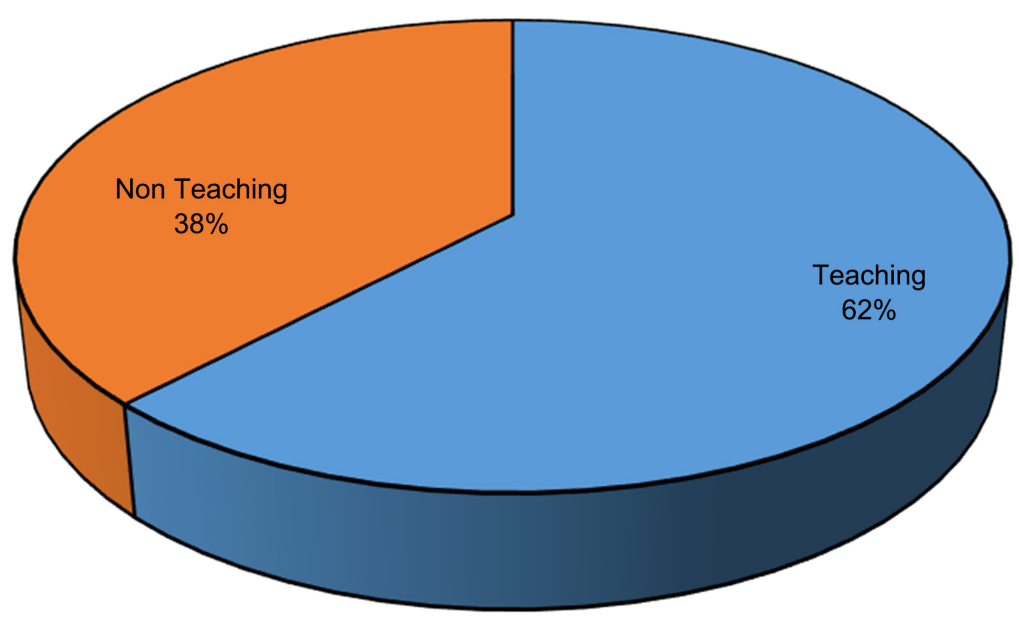

Figure 1. Employment category of the respondents. 
On the other hand, the non-teaching staff in higher education are responsible for the important day-to-day operations of a university [14]; they are required to report for work to address the immediate needs of the universities amidst this pandemic; in fact, some are even considered as front liners just like the security guards. They are considered front lines and have a ubiquitous presence because security guards play an important and essential role in guarding schools and government buildings to ensure round the clock security and safety at these places [15]. On top of that, during the pandemic, they are the first line of defense in screening visitors entering a building through temperature checks.

Sad to say, most of the non-teaching personnel hold a position under job order. Hence, they need to work because of the "no work, no pay scheme". While in other universities, the teaching personnel can work from home depending on the rules laid down by the university.

Therefore, for the long-term survival of today's colleges and universities, organizational strategies such as employee empowerment that promotes initiatives and creative behaviors among both the teaching and non-teaching staff become essential.

From Table 1, it can be seen that top universities in Nueva Ecija have made efforts to comply with protocols to ensure the protection and security of all stakeholders in this time of crisis by making facilities and equipment available for use.

The respondents strongly agreed that these universities ensure that the body temperatures of the individuals entering the campus are taken by thermal scanners so that people with elevated temperatures who may have symptoms can be prohibited from entering the university premises to prevent the potential transmission of the virus. Thermal scanners measure the heat on a person's skin and can be used to estimate whether someone is feverish-a potential sign of the disease caused by the virus, COVID-19 [16]. Thus, these universities purchased this aforementioned latest technology that could help detect who might be afflicted with this virus.

Correspondingly, the respondents strongly agreed that these universities are ensuring that there are logbooks and contact tracing forms to be filled out by visitors entering and leaving the campus. Because of contact tracing, people who have had close contact with someone who is infected with the virus are at higher risk of becoming infected and potentially infecting those they have had close contact with [17]. Thus, finding and monitoring these contacts after exposure to an infected person would help them to get adequate care and treatment, and could prevent further transmission of the virus.

Aside from these, the respondents also strongly agreed that there are signs posted on how to stop the spread of COVID-19 which indicates the promotion of everyday protective measures against the virus. According to [18], everyone can help stop COVID-19 by knowing the signs and symptoms that is why every organization is advised to have print materials to inform the public about the signs, symptoms, prevention, and other related information about the disease. 
Table 1. Availability of facilities and equipment.

\begin{tabular}{|c|c|c|c|}
\hline No. & Item Statement & $\begin{array}{l}\text { Weighted } \\
\text { Mean }\end{array}$ & $\begin{array}{c}\text { Verbal } \\
\text { Description }\end{array}$ \\
\hline 1 & $\begin{array}{c}\text { There are signs posted on how to stop the spread of } \\
\text { COVID-19 and indicates promotion on everyday } \\
\text { protective measures against the virus }\end{array}$ & 4.39 & Strongly Agree \\
\hline 2 & $\begin{array}{c}\text { There is a sanitation area for employees' vehicles } \\
\text { entering and leaving the campus }\end{array}$ & 4.15 & Agree \\
\hline 3 & $\begin{array}{l}\text { There are a logbook and contact tracing form to be } \\
\text { filled-out for visitors entering and leaving the campus }\end{array}$ & 4.47 & Strongly Agree \\
\hline 4 & $\begin{array}{c}\text { There are thermal scanners to take the body temperatures } \\
\text { of the people entering the campus so that individuals } \\
\text { with higher temperatures that may be afflicted with } \\
\text { the symptoms can be identified quickly }\end{array}$ & 4.49 & Strongly Agree \\
\hline 5 & $\begin{array}{l}\text { There is Personal protective equipment (PPE) which } \\
\text { includes safety helmets, gloves, eye protection, } \\
\text { high-visibility clothing, safety footwear and safety } \\
\text { harnesses for the personnel in-charge of conducting } \\
\text { thermal scanning at the entrance of the campus }\end{array}$ & 3.47 & Agree \\
\hline 6 & $\begin{array}{l}\text { There are accessible hand washing sinks in every } \\
\text { department/office and are fully stocked with soap, } \\
\text { paper towels, hand wash sign, and trash bins }\end{array}$ & 4.12 & Agree \\
\hline 7 & $\begin{array}{l}\text { There are mechanisms available on the bathroom doors } \\
\text { so they can be opened without directly touching them }\end{array}$ & 3.46 & Agree \\
\hline 8 & $\begin{array}{l}\text { There are hand sanitizers (minimum } 70 \% \text { alcohol) in } \\
\text { multiple locations to encourage hand hygiene by both } \\
\text { employees and clients to supplement hand washing }\end{array}$ & 4.32 & Strongly Agree \\
\hline 9 & $\begin{array}{l}\text { Facilities and equipment which are high touch self-service } \\
\text { items like chairs, tables, desktop, printer, etc. that are } \\
\text { considered prone to frequent hand contact are properly } \\
\text { washed, cleaned and sanitized, and changed regularly }\end{array}$ & 3.92 & Agree \\
\hline 10 & $\begin{array}{l}\text { Common areas like the bathroom, office lounge, } \\
\text { pantry, shared electronic equipment and even } \\
\text { ATMs are being cleaned and disinfected }\end{array}$ & 4.01 & Agree \\
\hline & Average Weighted Mean & 4.08 & Agree \\
\hline
\end{tabular}

Likewise, they strongly agreed that there are hand sanitizers (minimum 70\% alcohol) in multiple locations to encourage hand hygiene by both employees and clients to supplement hand washing. Throughout any given workday, employees use their hands to write up a report, open doors, and much more wherein all of these activities expose hands to harmful germs and bacteria [19]. Thus, it can be stated that the best way to remind employees to use hand sanitizer is by making it easily accessible and always within sight. 
On the other side of the picture, the respondents agreed that there are mechanisms available on the bathroom doors so they can be opened without directly touching them which only denotes that mechanics such as thermal doors cannot be easily acquired due to lack of resources of some universities and not all universities will prioritize allocating the budget in such technology.

The respondents also agreed that there is personal protective equipment (PPE) which includes safety helmets, gloves, eye protection, high-visibility clothing, safety footwear, and safety harnesses for the personnel in-charge of conducting thermal scanning at the entrance of the campus. This only implies that the security guards who are in charge of conducting the thermal scanning do not have the complete gears to get protected against the virus. According to [20], lack of adequate safety measures can put a security guard at unnecessary risk, so regardless of whether their job is to protect people, property, or assets, being equipped with the right protection is crucial to ensure their personnel safety isn't compromised.

In summary, the respondents acknowledged that facilities and equipment to prevent the spread of the virus are available, but others are still in need of improvement.

The data from Table 2 revealed that the respondents strongly agreed that the personnel in the different universities are mandated to wear face masks and face shields when dealing with co-workers and clients. In the Philippines, the use of a face shield and face mask becomes mandatory in the workplace since August 15, 2020, as per Labor Secretary Silvestre Bello III. Hence, the Inter-Agency Task Force for the Management of Emerging Infectious Diseases (IATF-EID) advocated for the use of face shields on top of face masks, along with observing social distancing as measures to lessen the chances of infection [21].

Likewise, the respondents strongly agreed that personnel is encouraged to practice proper coughing and sneezing etiquette at the workplace. According to [22], it is also important that companies provide proper and ongoing information related to the company's policies and practices related to COVID-19, including respiratory etiquette and personal hygiene. Therefore, the top management plays an important role in encouraging all of their employees to be vigilant about this outbreak by putting the safety of their employees first.

On the other side of the fence, the respondents agreed that personnel is subject to a regular rapid test to ensure that no asymptomatic employees are reporting to work. This only implies that not all employers are mandating their employees to subject themselves to a regular rapid test. The Department of Labor and Employment (DOLE) even reminded employers that COVID-19 testing is not a requirement before workers can return to work (Department of Health, 2020). Other than covering for the cost of the testing kits, employers who choose to test returning employees must comply with the DOH guidelines on Expanded Testing for COVID-19, that is why, most of the employers choose not to require testing; so, it can be presumed that asymptomatic employees might be everywhere in the workplace. 
Table 2. Personnel welfare.

\begin{tabular}{|c|c|c|c|}
\hline No. & Item Statement & $\begin{array}{l}\text { Weighted } \\
\text { Mean }\end{array}$ & $\begin{array}{c}\text { Verbal } \\
\text { Description }\end{array}$ \\
\hline 1 & $\begin{array}{l}\text { There is an existing protocol to check employees' health } \\
\text { and personal hygiene practices within the campus }\end{array}$ & 4.15 & Agree \\
\hline 2 & $\begin{array}{l}\text { The university regularly provides sanitation kit for } \\
\text { every employee in all campuses }\end{array}$ & 3.84 & Agree \\
\hline 3 & $\begin{array}{l}\text { Device schemes like having online transactions are being } \\
\text { encouraged as an alternative mode of communications } \\
\text { to avoid frequent contact among personnel }\end{array}$ & 4.29 & Strongly Agree \\
\hline 4 & $\begin{array}{l}\text { Personnel are provided with enough space at their } \\
\text { different offices for the observance of physical } \\
\text { social distancing }\end{array}$ & 4.29 & Strongly Agree \\
\hline 5 & $\begin{array}{l}\text { Personnel are mandated to wear face mask and face shield } \\
\text { when dealing with co-workers and clients }\end{array}$ & 4.62 & Strongly Agree \\
\hline 6 & $\begin{array}{l}\text { Personnel are encouraged to practice proper coughing } \\
\text { and sneezing etiquette at workplace }\end{array}$ & 4.49 & Strongly Agree \\
\hline 7 & $\begin{array}{l}\text { Personnel residing at barangays under lockdown due to a } \\
\text { presence of COVID-19 positive case are discouraged to } \\
\text { physically report to work and are encouraged to do a } \\
\text { self-home quarantine }\end{array}$ & 4.25 & Strongly Agree \\
\hline 8 & $\begin{array}{l}\text { Personnel with above normal body temperature are } \\
\text { not allowed to enter the school }\end{array}$ & 4.30 & Strongly Agree \\
\hline 9 & $\begin{array}{l}\text { Personnel are subject to a regular rapid test to } \\
\text { ensure that no asymptomatic employees are } \\
\text { reporting to work }\end{array}$ & 3.52 & Agree \\
\hline \multirow[t]{2}{*}{10} & $\begin{array}{l}\text { Personnel having symptoms during office hours are } \\
\text { immediately referred to proper authorities to ensure } \\
\text { the safety of his co-workers }\end{array}$ & 4.16 & Agree \\
\hline & Average Weighted Mean & 4.19 & Agree \\
\hline
\end{tabular}

In addition to this, respondents also agree that their universities normally provide sanitation kits for every employee on all campuses, which means that some universities might have provided sanitation kits upon reopening, but it does not happen regularly.

Since the respondents just agreed that there is an existing protocol to check employees' health and personal hygiene practices within the campus; it can be alleged that not all universities are giving attention to determining their employees' health and sanitation practices. According to [23], employers should start doing these things now, even if COVID-19 has not arrived in the communities where they operate since these measures can reduce working days lost due to illness and stop or slow the spread of COVID-19 if it arrives at one of your workplaces. 


\subsection{Proposed Enhancement Plan}

The triangulation of activities is vital to determine the capacity of the institution to actualize the Enhancement Plan. As shown in Table 3, the plan is subdivided into three major areas of consideration, the facilities and equipment (tools); personnel welfare (users), and; the policies/guidelines and restrictions (regulations) which will enable the institutions to triangularly apply the aforementioned activities based on resources cited in the plan.

For the facilities and equipment area, the focus of this consideration is to enhance the equipment and facilities of the institution based on the current needs assessment of the top and middle management.

For the personnel welfare, the focus of this consideration is to add several-fold of information regarding proper health protocols with the demonstration that will enable the target stakeholders of the university to actualize what is written and what is stated in the health protocols.

Table 3. Enhancement plan.

\begin{tabular}{|c|c|c|c|c|c|c|}
\hline $\begin{array}{c}\text { Areas of } \\
\text { Consideration } \\
\text { for } \\
\text { Triangulation }\end{array}$ & Objective & Activities & Resources & $\begin{array}{c}\text { Responsible } \\
\text { Agency/Department }\end{array}$ & Time Frame & $\begin{array}{l}\text { Success } \\
\text { Indicator }\end{array}$ \\
\hline $\begin{array}{l}\text { Facilities } \\
\quad \text { and } \\
\text { Equipment }\end{array}$ & $\begin{array}{l}\text { To improve } \\
\text { the existing } \\
\text { facilities by } \\
\text { harmoniously } \\
\text { adapting the } \\
\text { enhanced } \\
\text { rules and } \\
\text { regulations }\end{array}$ & $\begin{array}{l}\text { Benchmark to other institutions } \\
\text { with commendable or remarkable } \\
\text { performance in terms of } \\
\text { advancement of technology. } \\
\text { Given the perspective of walk-ins } \\
\text { and volume of population, the } \\
\text { universities walk-in transactions is } \\
\text { almost equitable or comparable to } \\
\text { the potentials of health facilities, } \\
\text { thus building triage for walk-in } \\
\text { transactions are hereby } \\
\text { recommended, likewise, if it is not } \\
\text { possible to enact a triage due to a } \\
\text { very limited resources, the universities } \\
\text { are also encouraged to create a certain } \\
\text { booth for through interview using } \\
\text { the instrument utilized by different } \\
\text { health care facilities } \\
\text { Maximizing electronic transaction } \\
\text { to minimize the operational cost of } \\
\text { the institution and allowing some } \\
\text { workforce to do or to serve at home } \\
\text { especially those who are involved in } \\
\text { the task. Instruction, research and } \\
\text { contemporary design of extension } \\
\text { activities can be made on online } \\
\text { platforms-thus, an effective tool } \\
\text { jeopardizing operational outputs. }\end{array}$ & $\begin{array}{l}\text { A multi-disciplinary } \\
\text { taskforce for } \\
\text { benchmarking } \\
\text { The identified } \\
\text { tools and } \\
\text { equipment } \\
\text { necessary for } \\
\text { building triage }\end{array}$ & $\begin{array}{l}\text { Budget Office } \\
\text { Procurement } \\
\text { Office } \\
\text { A Multi-disciplinary } \\
\text { taskforce }\end{array}$ & $\begin{array}{l}\text { Present up to } \\
\text { the extent that } \\
\text { the pandemic } \\
\text { ends }\end{array}$ & $\begin{array}{c}\text { Few otherwise } \\
\text { favorable } \\
\text { doubling rate }\end{array}$ \\
\hline
\end{tabular}




\section{Continued}

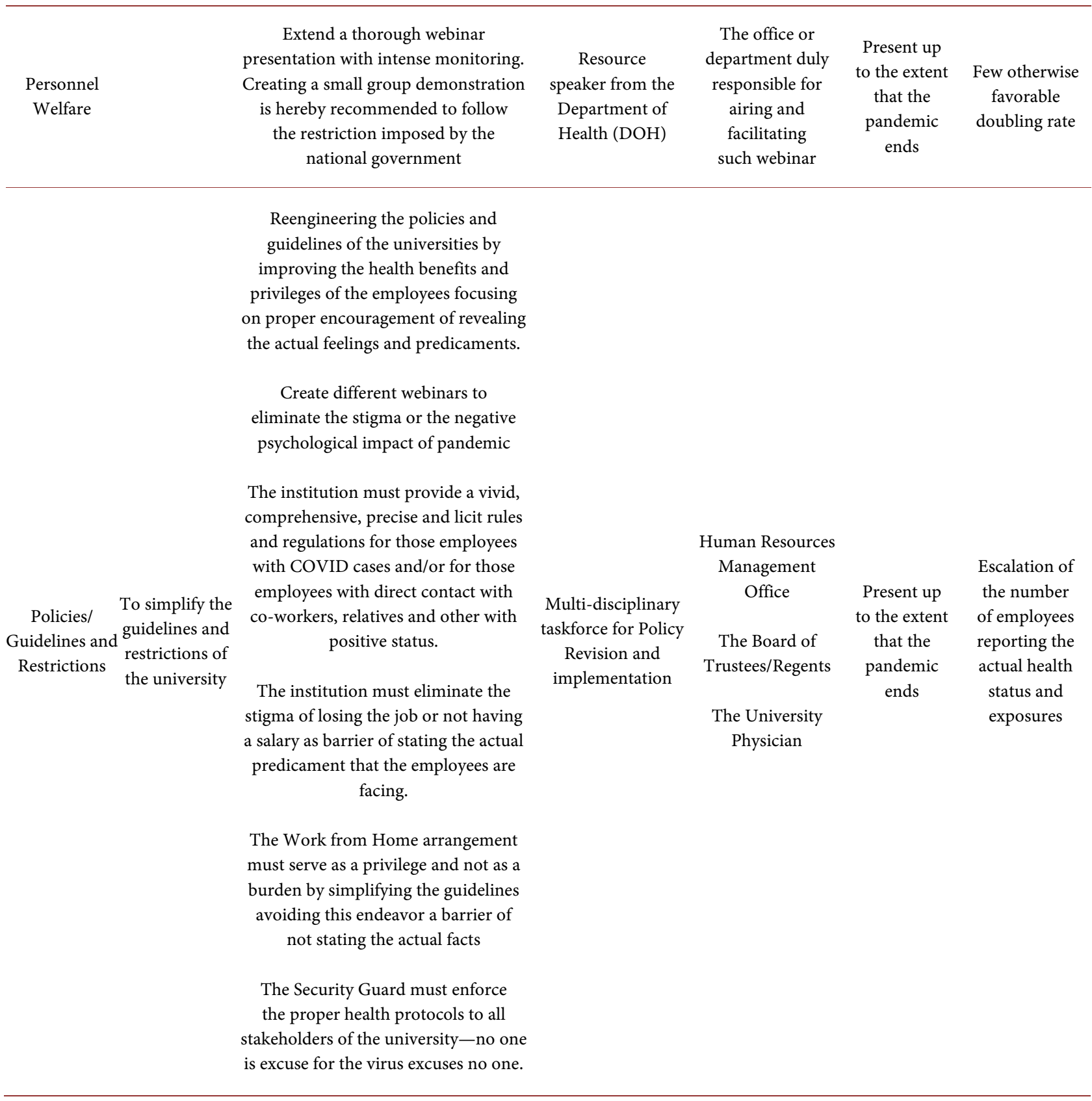

For the policies, guidelines, and restrictions, the focus of this consideration is to eliminate the stigma of losing job and income, more so, to rectify rules and regulations that will help the universities and institutions stakeholders to declare their actual predicament by harmonizing or balancing the rules and regulations without jeopardizing the quality, standard and productivity level of the school involved.

\section{Conclusion and Recommendation}

The top universities in Nueva Ecija, Philippines, have made efforts to ensure the 
safety of university workers by complying with the IATF protocols. It can be inferred, in reality, that protection and safety measures have been enforced and strictly observed. At the same time, it cannot be denied that, particularly in times of extraordinary circumstances like this virus outbreak, there is no perfect plan and execution. Due to this, some areas still need enhancement because there are other uncontrollable variables such as low-human adaptation in both psychological and physical that must be considered and should be given much attention.

The following recommendations are given based on the results and conclusions of this study: top management should review their current policies, guidelines, and health protocols in their battle against the COVID-19 pandemic. Just the same, they have to listen to the insights of their employees about their current health protocol, especially whether their employees feel safe or not about how they cope with the new normal situation; they should even ask their staff for feedback about how their current practices can be strengthened. Finally, the researchers suggest to them an enhancement plan that can significantly assist the numerous universities in the fight against the COVID-19 pandemic.

\section{Conflicts of Interest}

The authors declare no conflicts of interest regarding the publication of this paper.

\section{References}

[1] Calonzo, A. and Jiao, C. (2020) Duterte Expands Philippine Lockdown to 60 Million People.

https://www.bloomberg.com/news/articles/2020-03-16/duterte-widens-lockdown-to -main-philippine-island-to-fight-virus

[2] Prasetyo, Y.T., Castillo, A.M., Salonga, L.J., Sia, J.A. and Seneta, J.A. (2020) Factors Affecting Perceived Effectiveness of COVID-19 Prevention Measures among Filipino during Enhanced Community Quarantine in Luzon, Philippines: Integrating Protection Motivation Theory and Extended Theory of Planned Behavior. International Journal of Infectious Diseases, 99, 312-323. https://doi.org/10.1016/j.ijid.2020.07.074

[3] Atalan, A. (2020) Is the Lockdown Important to Prevent the COVID-19 Pandemic? Effects on Psychology, Environment and Economy-Perspective. Annals of Medicine and Surgery, 56, 38-42. https://doi.org/10.1016/j.amsu.2020.06.010

[4] Ansari, T., Khan, N. and Schwartz, F. (2020) More Countries Take Measures to Reopen Parts of Daily Life.

https://www.msn.com/en-us/news/world/more-countries-take-measures-to-reopen -parts-of-daily-life/ar-BB13dh39

[5] Caselli, M., Fracasso, A. and Scicchitano, S. (2020) From the Lockdown to the New Normal: An Analysis of the Limitations to Individual Mobility in Italy Following the COVID-19 Crisis. GLO Discussion Paper, No. 683, Global Labor Organization, Essen. http://hdl.handle.net/10419/225064 https://doi.org/10.2139/ssrn.3710568

[6] Anicich, E.M., Foulk, T.A., Osborne, M.R., Gale, J. and Schaerer, M. (2020) Restore 
Your Sense of Control-Despite the Pandemic. https://hbr.org/2020/09/restore-your-sense-of-control-despite-the-pandemic

[7] International Labor Organization (2020) Safe Return to Work: Ten Action Points. https://www.ilo.org/global/topics/safety-and-health-at-work/resources-library/publi cations/WCMS_745541/lang--en/index.htm

[8] Department of Labor and Employment (2020) Workplace Rules Set to Cut Spread of COVID-19.

https://www.dole.gov.ph/news/workplace-rules-set-to-cut-spread-of-covid-19/

[9] Magsambol, B. (2020) Revert COVID-19 'High-Risk' Areas to Stricter Quarantine-Experts.

https://www.rappler.com/nation/up-researchers-recommendation-revert-coronavir us-high-risk-areas-stricter-quarantine-measure

[10] Kumar, R. (2011) Research Methodology: A Step by Step Guide for Beginners. 3rd Edition, Sage, London.

[11] Black, K. (2010) Business Statistics: Contemporary Decision Making. 6th Edition, John Wiley and Sons, Hoboken.

[12] González, G.M. (2019) Changing with the Times: Faculty's Role in Delivering a Great Student Experience.

https://evolllution.com/programming/teaching-and-learning/changing-with-the-ti mes-facultys-role-in-delivering-a-great-student-experience/

[13] Austin, A.E. and Hill, L.B. (2014) University Faculty Roles and Responsibilities in the United States. https://doi.org/10.1093/obo/9780199756810-0070

https://www.oxfordbibliographies.com/view/document/obo-9780199756810/obo-97 $\underline{80199756810-0070 . x m l}$

[14] Lau, W.K.J. (2010) Empowerment of Non-Academic Personnel in Higher Education: Exploring Associations with Perceived Organizational Support for Innovation and Organizational Trust. Doctor of Philosophy Thesis, University of Iowa, Iowa City.

[15] Mohtar, J. (2020) The 'Forgotten' Frontliner and Third Line of Defence. https://www.emirresearch.com/the-forgotten-frontliner-and-third-line-of-defence/

[16] Harwell, D. (2020) Thermal Scanners Are the Latest Technology Being Deployed to Detect the Coronavirus. But They Don't Really Work.

https://www.washingtonpost.com/technology/2020/05/11/thermal-scanners-are-late st-technology-being-deployed-detect-coronavirus-they-dont-really-work/

[17] Sagar, M. (2020) The Importance of Contact Tracing in Singapore and the Role Technology Plays.

https://opengovasia.com/the-importance-of-contact-tracing-in-singapore-and-the-r ole-technology-plays/

[18] Centers for Disease Control and Prevention (2020) Know the Facts about Coronavirus Disease 2019.

https://www.cdc.gov/coronavirus/2019-ncov/daily-life-coping/share-facts.html

[19] Faivre, I. (2018) The Importance of Hand Sanitizer Placement in the Workplace. https://info.debgroup.com/blog/the-importance-of-hand-sanitizer-placement-in-th e-workplace

[20] Lone, A. (2015) Personal Protective Equipment for Security Guards. https://www.lonealert.co.uk/lone-working/latest-news/personal-protective-equipme nt-for-security-guards/

[21] Abadilla, E.V. (2020) Face Shields Mandatory for PUV Passengers, in Workplace 
Starting Today.

https://mb.com.ph/2020/08/15/face-shields-mandatory-for-puv-passengers-in-work place-starting-today/

[22] Holland and Hart, L.L.P. (2020) Best Practices for Safe and Healthy Workplaces During COVID-19.

https://www.lexology.com/library/detail.aspx?g=43344441-d172-4963-b004-4f3379f $\underline{\mathrm{d} 8 \mathrm{~d} 39}$

[23] World Health Organization (2020) Getting Your Workplace Ready for COVID-19. https://www.who.int/docs/default-source/coronaviruse/advice-for-workplace-clean19-03-2020.pdf 